\title{
Program Bantu Sistem Analisis Manajemen Risiko
}

\author{
Dihin Muriyatmoko, Edi Satriyanto, Eru Puspita \\ Politeknik Elektronika Negeri Surabaya \\ Institut Teknologi Sepuluh Nopember (ITS) Surabaya
}

\begin{abstract}
ABSTRAK
Manajemen risiko merupakan suatu pendekatan yang komprehensif yang jarang diterapkan di Indonesia oleh departemen khusus. Penerapan manajemen risiko secara efektif dan efisien sulit dilakukan di Indonesia karena adanya perbedaan persepsi dan sikap dalam mendefinisikan risiko.

Program bantu sistem analisis manajemen risiko ini bertujuan untuk memberikan alternatif solusi dalam menghadapi risiko dan memberikan rekomendasi atau keputusan untuk menentukan solusi yang akan diambil dari suatu permasalahan.

Keputusan yang diambil didasarkan atas perhitungan ilmiah, praktisi, prediksi maupun pengalaman atau kebiasaan. Metode yang digunakan dalam mengambil keputusan adalah uraian solusi berdasarkan level risiko, sehingga dari setiap solusi yang dihasilkan akan dihitung nilainya dan ditentukan mana solusi yang akan diambil.
\end{abstract}

\section{ABSTRACT}

Risk management is a comprehensive approach that is seldom Utilized by specialized division in Indonesia. Applying risk management efectively and efficiently is hard because there are differences in perception and attitude to define the risk.

This program to assist in analysis risk management system aims to provide alternative solutions in the face of risks and provide recommendations or decisions to determine the solution that will be taken out of a problem.

Decision made based on scientific calculations, practitioners, and the predicted behavior or experience. Methods used in decision making is based on the description level risk solutions, so that every solution of the resulting value will be calculated and determined where the solution that will be taken.

\section{Pendahuluan}

Selaras dengan perkembangan dunia dan teknologi yang semakin maju pesat, tentunya akan membawa peluang yang semakin besar pula. Besarnya peluang tentu akan mempengaruhi juga faktor risiko, karena dengan berani mengambil sebuah peluang berarti harus berani menanggung resiko yang bersifat merugikan. Dengan demikian, resiko yang tidak dikendalikan dengan baik, akan membawa kearah kehancuran. Resiko yang terjadi bisa berasal dari dalam (intern) maupun luar (ekstern) institusi. Untuk membantu meningkatkan unsur pengendalian intern, maka dilakukan upaya pengawasan, pengamanan peluang yang ada dengan menggunakan metode terstruktur, meliputi prediksi, perhitungan bisnis, maupun berdasarkan pengalaman.

Eksekutif dalam perusahaan umumnya telah menyadari adanya risiko di dalam perusahaannya, namun masing - masing dari eksekutif tersebut masih mempunyai persepsi dan sikap yang berbeda dalam mendefinisikan risiko. Mereka cenderung melakukan penanganan sendiri sesuai dengan kepentingan masing - masing departemen, sehingga penanganan risiko menjadi kurang efektif dan efisien, maka sistem manajemen yang sistematis dan terstruktur sangat dibutuhkan dalam perusahaan.

\section{Dasar Teori}

Perusahaan atau organisasi yang berskala besar seringkali menjumpai spektrum risiko yang cukup besar sehingga diperlukan suatu divisi khusus untuk menganalisa segala bentuk risiko yang mungkin terjadi. Peran seorang manajer risiko sangat diperlukan untuk menangani segala bentuk risiko di perusahaan dengan pendekatan manajemen risiko yang sistematis.

Teori - teori tentang pendifinisian risiko dan manajemen risiko secara baku dirasakan perlu sebelum pembahasan tentang proses identifikasi risiko, klasifikasi risiko, analisa risiko dan pengambilan sikap terhadap risiko dalam suatu perusahaan. Teori tersebut sangat membantu dan bermanfaat bagi suatu perusahaan.

\subsection{Definisi Risiko}

Istilah risiko mempunyai banyak pengertian dalam kegiatan usaha dan kehidupan sehari - hari. Beberapa literatur mendefinisikan kata risiko dalam pengertian yang berbeda - beda. Kebanyakan definisi risiko difokuskan pada kerugian atau kerusakan.

Definisi risiko secara umum dapat dikatakan sebagai suatu ketidakpastian dalam memprediksi suatu kejadian dimasa yang akan datang.

\subsection{Manajemen Risiko}

- Definisi manajemen risiko

Istilah manajemen risiko mempunyai arti yang luas sesuai dengan bidang yang dimiliki. Definisi manajemen risiko menunjukkan bahwa secara umum manajemen risiko berhubungan dengan proses identifikasi, klasifikasi, analisa dan pengambilan sikap terhadap risiko yang akan diuraikan dalam penjelasan proses manajemen risiko.

\section{- Manfaat manajemen risiko}

Manfaat manajemen risiko yang diberkan terhadap perusahaan dapat dibagi menjadi lima kategori utama sebagai berikut (Darmawi, 2005, p. 11):

1. Manajemen risiko mungkin dapat mencegah perusahaan dari kegagalan

2. Manajemen risiko menunjang secara langsung peningkatan laba

3. Manajemen risiko dapat memberikan laba secara tidak langsung

4. Adanya ketenangan pikiran bagi manajer yang disebabkan oleh adanya perlindungan terhadap risiko murni, merupakan harta nonmaterial bagi perusahaan itu. 
5. Manajemen risiko melindungi perusahaan dari risiko murni dan karena kreditur pelanggan dan pemasok lebih menyukai perusahaan yang dilindungi maka secara tidak langung menolong meningkatkan public image.

\subsection{Proses Manajemen Risiko}

Tujuan dari manajemen risiko adalah untuk memaksimalkan nilai (value) dari perusahaan dengan meminimasi biaya dari risiko murni (Trieschmann and Gustavson, 1995, p. 22).

Penetapan tujuan dan sasaran manajemen risiko sangatlah penting, karena tujuan dan sasaran itulah yang merupakan dasar dari semua aktifitas manajemen risiko, tujuan dan sasaran tersebut merupakan tolak ukur bagi kesuksesan dan kegagalan pada program atau kegiatan yang dijalankan, selain itu juga untuk menentukan filosofi dasar dari aktifitas manajemen risiko (William, et. al. , 1995, p. 32)

Tahap - tahap proses manajemen risiko menurut The Australian and New Zeeland Standart (AS/NZS 4360:2004) adalah sebagai berikut :
a. Establish the context
b. Risk Identification
c. Risk classification
d. Risk analysis
e. Risk evaluation
f. Risk treatment
g. Monitoring and review
h. Communication and consultation

\subsection{JSP (Java Server Pages)}

JSP merupakan suatu bahasa program yang digunakan untuk mengembangkan suatu aplikasi server side berbasis java dan bertujuan untuk menyederhanakan pembuatan dan manajemen halaman web yang bersifat dinamis, dengan cara memisahkan content dan presentasi. JSP merupakan halaman yang menggabungkan HTML dengan scripting tag dan program java. Pada saat JSP dipanggil client melalui browser, JSP tersebut akan di kompile terlebih dahulu menjadi servlet, dan kemudian hasilnya dikembalikan ke client.

Salah satu bagian yang biasa digunakan pada suatu aplikasi web adalah menggunakan Form HTML yang digunakan untuk memasukan beberapa informasi oleh pengguna. Informasi yang dimasukan pengguna akan disimpan pada request objek, dimana dikirim oleh client ke JSP engine. Kemudian JSP engine akan mengirimkan request objek tersebut ke server-side component (JavaBean component, servlet, atau enterprise bean ) untuk file JSP tertentu yang di request oleh client.

Selanjutnya component menangani request tersebut dan memberikan kembali response objek ke JSP engine. JSP engine memberikan response objek terhadap halaman JSP yang di-request oleh client dalam format HTML baru. Adapun untuk ilustrasinya diberikan pada gambar sebagai berikut :

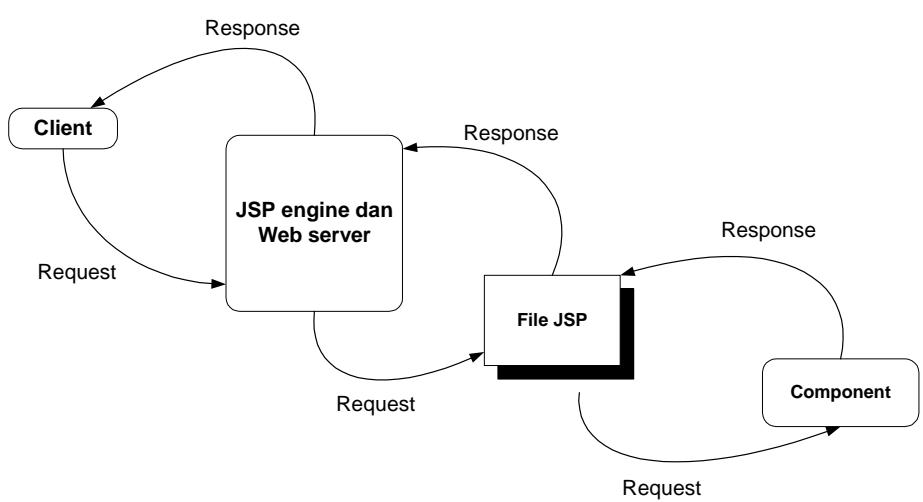

Gambar 2.1 Aliran Data Antara Client dan Server

\subsection{JSP dan Database}

JSP sebagai teknologi untuk pembuatan aplikasi web memiliki kemampuan menangani database dengan menggunakan class dan interface Java Database Connectivity ( JDBC ) sebagai driver antara program JSP dan database server. Untuk masing-masing database memiliki JDBC driver sendiri-sendiri.

\section{$2.6 \quad$ JDBC}

JDBC adalah Application Programming Interface (API) yang dikembangkan oleh Sun Microsystem untuk menyediakan akses data universal dalam bahasa pemrograman Java. Inti JDBC adalah package java.sql dan javax.sql. JDBC menyediakan mekanisme untuk koneksi database, query database, dan traksaksi database. JDBC tidak melakukan standarisasi SQL, tetapi dapat mendukung sintaks SQL untuk masing-masing vendor database.

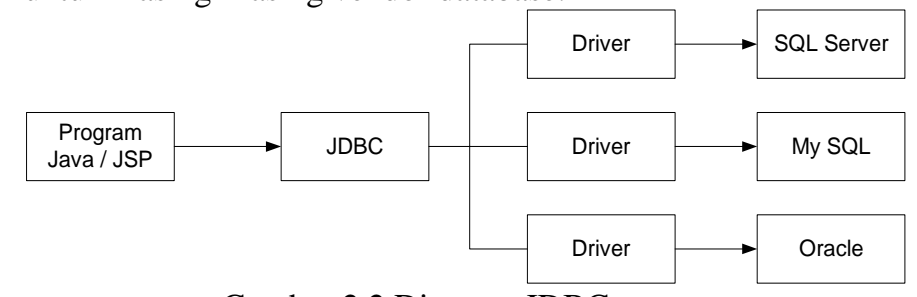

Gambar 2.2 Diagram JDBC

JDBC bukan database server, tetapi merupakan penyedia mekanisme untuk berkomunikasi antara aplikasi Java dan database server

\subsection{Java}

Java merupakan sebuah bahasa pemrograman yang dikeluarkan oleh Sun Microsystem (http://java.sun.com) pada bulan November 1995. Java termasuk dalam kategori Pemrograman Berorientasi Obyek. Bahasa ini sebelum bernama Java dinamakan Oak yang diciptakan oleh James Gosling ${ }^{13}$. Java merupakan bahasa yang dapat diterapkan pada berbagai macam platform. Keistimewan dari Oak - dan oleh karenanya diwarisi oleh Java - adalah kedekatannya dengan Internet. Salah satu keistimewaan Java yang paling banyak dikenal orang adalah ia dapat menciptakan program yang dieksekusi melalui browser internet. Program ini disebut applet.

\subsection{Java Development Kit (JDK, versi 1.4)}

JDK adalah suatu perangkat lunak yang dikeluarkan oleh Sun Microsystem untuk membuat 
aplikasi, applet, dan komponen yang dapat dijalankan dalam platform Java. JDK mempunyai fasilitas untuk mengembangkan dan menguji program yang ditulis dalam bahasa Java dan dijalankan dalam platform Java. Fasilitas-fasilitas ini hanya dapat dieksekusi melalui perintah yang dituliskan di command line, kecuali untuk appletviewer. Jadi, fasilitas-fasilitas pada JDK 1.4 tidak memiliki Graphical User Interface (GUI).

\subsection{Jakarta Tomcat}

Jakarta Tomcat merupakan sebuah servlet container yang juga dapat berfungsi sebagai web server. Jakarta Tomcat, seperti halnya Xalan Java merupakan software yang open source. Dalam skripsi ini, Jakarta Tomcat yang digunakan adalah versi 3.3 yang dikeluarkan tanggal 18 April 2002. Sampai sekarang Jakarta Tomcat telah mencapai versi 6.0 yang dikeluarkan pada bulan Oktober 2002. Jakarta Tomcat merupakan implementasi resmi (official implementation) dari teknologi Java Servlet dan Java Server Page (JSP). Dengan Jakarta Tomcat kita dapat menjalankan aplikasi server side yang dibuat dengan Java.

\subsection{Database MySQL}

MySQL adalah multiuser database yang menggunakan bahasa Structure Query Languange (SQL). MySQL dalam operasi client-server melibatkan server daemon MySQL disisi server dan berbagai macam program serta library yang berjalan di sisi client. SQL adalah bahasa standar yang digunakan untuk mengakses database server.

MySQL sebenarnya merupakan turunan salah satu konsep utama dalam database sejak lama, yaitu SQL (Structure Query Language). SQL adalah sebuah konsep pengoperasian database, terutama untuk pemilihan/seleksi dan pemasukan data, yang memungkinkan pengoperasian data dikerjakan dengan mudah secara otomatis.

Keandalan suatu system database (DBMS) dapat diketahui dari cara kerja optimizer-nya dalam melakukan proses perintah-perintah SQL, yang dibuat oleh user maupun program-program aplikasinya. Sebagai database server, MySQL dapat dikatakan lebih unggul dibandingkan dengan database server yang lainnya dalam query data.

\section{Metode dan Perancangan}

\section{- Analisis Manajemen Risiko}

Analisis risiko dapat memberikan penilaian yang signifikan terhadap setiap risiko terhadap faktor faktor didalamnya agar risiko tersebut dapat dikendalikan. Risiko dapat dikatakan sebagai kejadian yang tidak pasti dan dapat diselesaikan dengan akibat kualitatif dan skala kemungkinan serta suatu matriks yang menentukan kombinasi dari keduanya.

Berikut ini tabel yang menjelaskan mengenai skala kemungkinan atau likehood (kemungkinan dari kejadian buruk yang terjadi) dan akibat kualitatif atau concequence (hasil atau akibat dari kejadian buruk yang terjadi).

\begin{tabular}{|l|c|c|c|c|c|}
\hline \multirow{2}{*}{ Likehood } & \multicolumn{5}{|c|}{ Concequence for each Factor } \\
\cline { 2 - 6 } & $\begin{array}{c}\text { Tidak } \\
\text { berat }\end{array}$ & $\begin{array}{c}\text { Agak } \\
\text { berat }\end{array}$ & Berat & $\begin{array}{c}\text { Sangat } \\
\text { berat }\end{array}$ & $\begin{array}{c}\text { Malap- } \\
\text { etaka }\end{array}$ \\
\hline & $\mathbf{1}$ & $\mathbf{2}$ & $\mathbf{3}$ & $\mathbf{4}$ & $\mathbf{5}$ \\
\hline 1. Sangat besar & $\mathrm{T}$ & $\mathrm{T}$ & $\mathrm{E}$ & $\mathrm{E}$ & $\mathrm{E}$ \\
\hline 2. Besar & $\mathrm{M}$ & $\mathrm{T}$ & $\mathrm{T}$ & $\mathrm{E}$ & $\mathrm{E}$ \\
\hline 3. Sedang & $\mathrm{R}$ & $\mathrm{M}$ & $\mathrm{T}$ & $\mathrm{E}$ & $\mathrm{E}$ \\
\hline 4. Kecil & $\mathrm{R}$ & $\mathrm{R}$ & $\mathrm{M}$ & $\mathrm{T}$ & $\mathrm{E}$ \\
\hline 5. Sangat kecil & $\mathrm{R}$ & $\mathrm{R}$ & $\mathrm{M}$ & $\mathrm{T}$ & $\mathrm{T}$ \\
\hline
\end{tabular}

Tabel 3.1 Matriks manajemen risiko

Sumber Pardamean Ronitua Harahap, Asian Business Consultants, p. 41

\begin{tabular}{|c|l|l|}
\hline Rangking & \multicolumn{1}{|c|}{ Risk } & \multicolumn{1}{c|}{ Required action } \\
\hline $\mathrm{E}$ & Extreme & License / stakeholder required \\
\hline $\mathrm{T}$ & High & Senior management attention required \\
\hline $\mathrm{M}$ & Moderate & $\begin{array}{l}\text { Management responbility must be } \\
\text { spesified }\end{array}$ \\
\hline $\mathrm{R}$ & Low & Manage by routine procedure \\
\hline
\end{tabular}

Tabel 3.2 Rangking key matriks manajemen resiko Sumber Pardamean Ronitua Harahap, Asian Business Consultants, p. 41

\section{- Arsitektur Aplikasi JSP}

Alur kerja dari JSP diawali dari pemakai yang ingin mengakses halaman Web mula-mula mengirimkan permintaan halaman Web melalui protokol HTTP (HyperText Transfer Protocol) dalam bentuk JSP (berekstensi .jsp). Permintaan ini akan disampaikan ke Web server. Kemudian Web server menyesuakan dengan database yang ada dan mengambil dokumen JSP dan mengirimkan ke JSP Servlet Engine. Bagian inilah yang melakukan pemrosesan kode-kode JSP (termasuk di dalamnya melakukan pengompilasian) dan membentuk kode HTML. Berikutnya, kode HTML ini disampaikan oleh Web server ke klien yang memintanya. Kode HTML ini selanjutnya diproses oleh browser sehingga pemakai bisa memperoleh informasi dari halaman Web yang dikehendakinya.

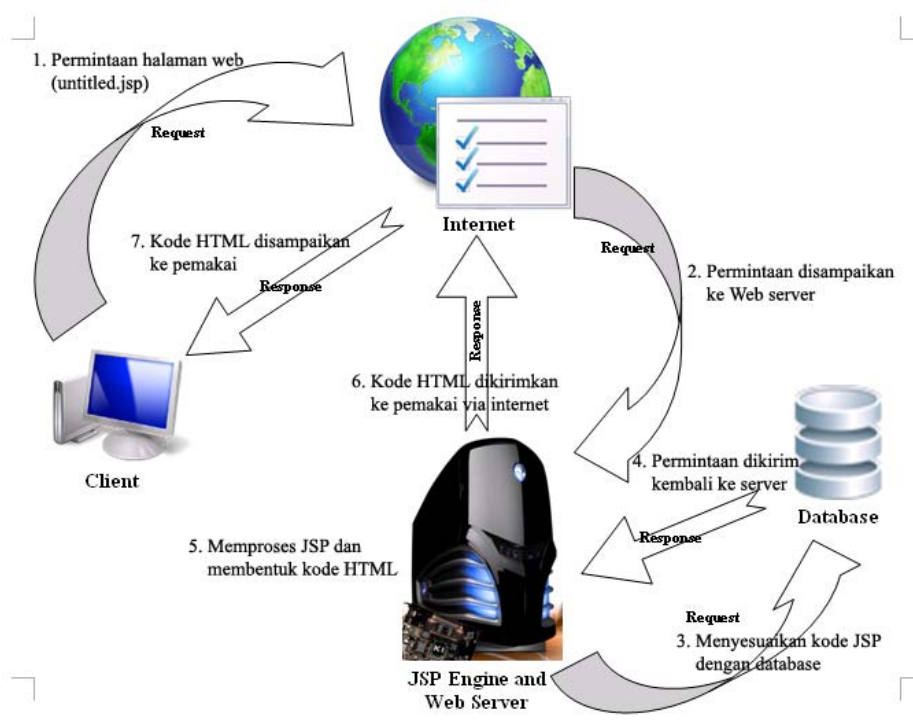

Gambar 3.1. Servlet/ JSP Application Architecture. 


\section{- Flowchart Operasional Software}

Alur dari software ini dimulai dari suatu masalah yang muncul akan dicari berbagai solusi yang mungkin. Setiap solusi tentu mempunyai risiko, baik besar maupun kecil akan diperhitungkan kelayakannya. Risiko tadi akan dianalisa skala kemungkinan dan akibat kualitatif dari setiap faktor yang ada, sehingga berdasarkan tabel matriks dan rangking key manajemen risiko seperti dijelaskan diatas maka setiap risiko dapat ditentukan levelnya.

Dari risiko - risiko tersebut akhirnya dapat diperoleh hasil nilai dari setiap solusi yang nantinya akan dipilih salah satu dan dijadikan sebagai rekomendasi atau keputusan yang diprioritaskan untuk menyelesaikan suatu masalah. Rekomendasi ini didasarkan secara perhitungan ilmiah, praktisi, prediksi maupun kebiasaan/ pengalaman. Saran atau rekomendasi tidak bersifat mutlak, tetapi harus dikaji lagi berdasarkan keadaan dan kondisi riil dengan melakukan analisis dari berbagai bidang.

Dengan demikian, manajemen resiko dapat memberikan keluaran berupa tahapan penyelesaian masalah, sesuai prosedur yang diinginkan, dengan meminimkan resiko yang ada.

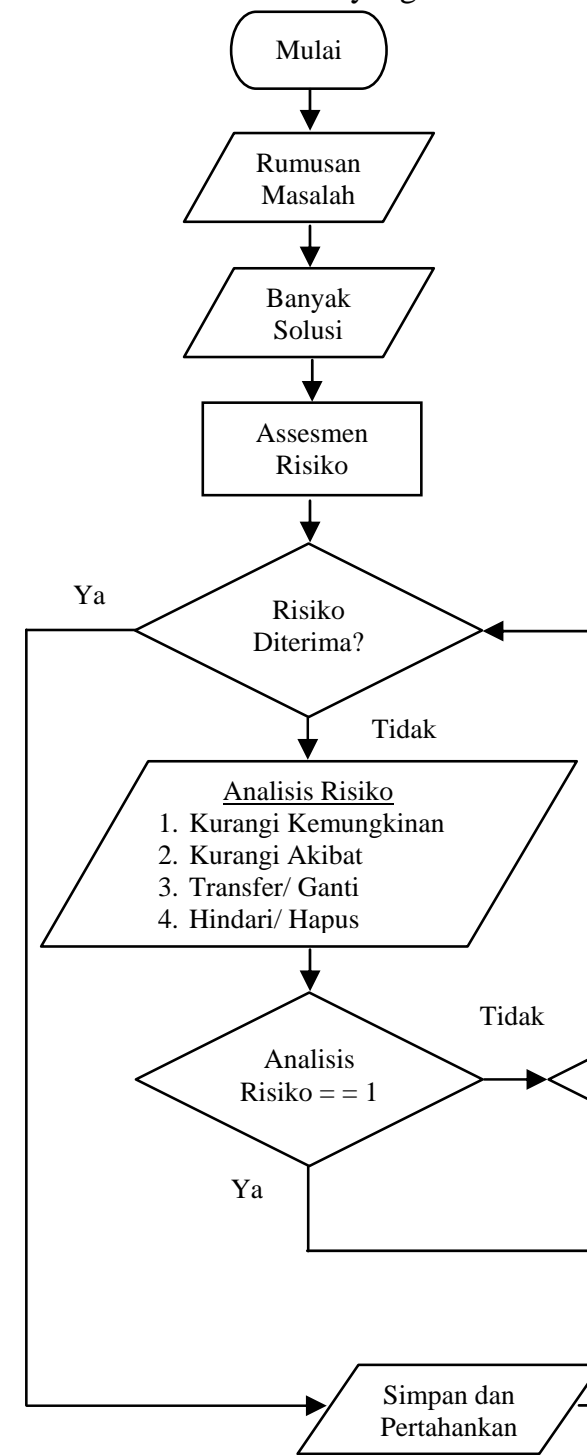
Pertahankan

Gambar 3.2 Flowchart Operasional Software Sistem Analisis Manajemen Risiko
4. Hasil Pengujian dan Analisa

4.1 Analisa Manajemen Risiko
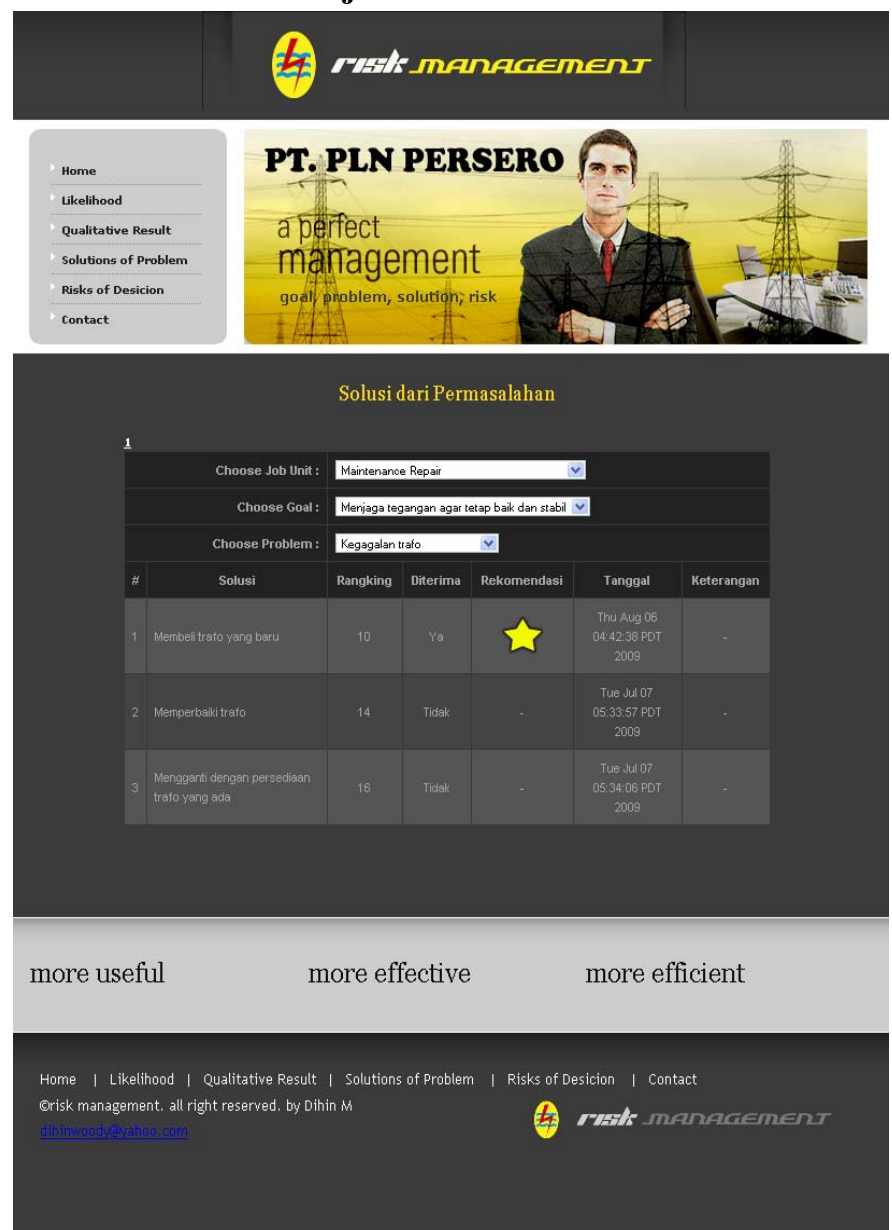

Gambar 4.1 Preview Keputusan Manajemen Risiko pada Halaman Utama 


\subsection{Pengujian Manajemen Risiko}

Suatu struktur organisasi memasukkan nama unit kerja, tujuan, masalah dan solusinya. Kemudian dari setiap solusi diberikan risiko-risiko yang mungkin terjadi. Setiap risiko tersebut diberikan prosentase skala kemungkinan dan akibat kualitatif setiap faktor analisis yang akan dikombinasikan dengan matriks risiko.

Setelah disesuaikan dengan matriks risiko maka setiap risiko akan mendapatkan rangking key, level risiko dan nilai yang akan digunakan untuk perhitungan sebuah solusi. Semua risiko dari salah satu solusi akan dihitung dan ditentukan nilai dan status diterima tidaknya suatu solusi.

Tim atau Manajer Manajemen Risiko akan memutuskan manakah solusi yang akan diambil dan diterima untuk pemecahan suatu masalah. Solusi yang dinyatakan "Diterima" dari Hasil Keputusan Analisis Manajemen Risiko akan ditandai dengan tulisan "Ya" pada kolom diterima.

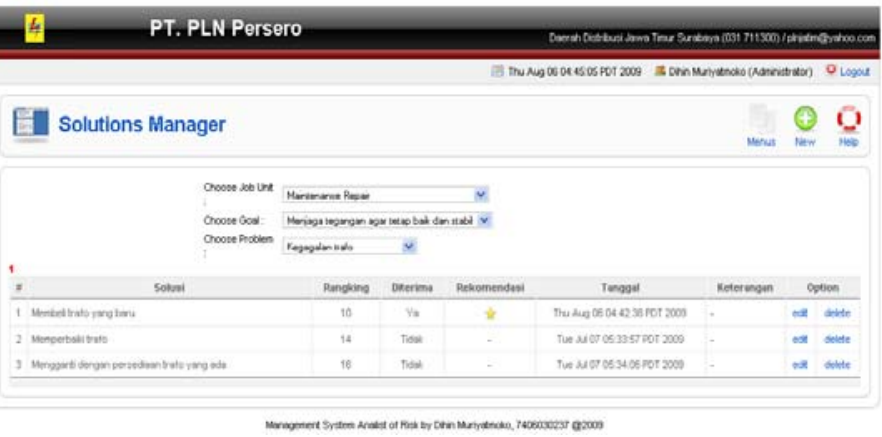

Gambar 4.2 Preview Keputusan Manajemen Risiko pada Halaman Administrator

Penjelasan dari gambar diatas adalah

\begin{tabular}{|c|c|c|c|c|}
\hline No & Solusi & Nilai & Diterima & Rekomendasi \\
\hline 1 & $\begin{array}{l}\text { Membeli trafo } \\
\text { yang baru }\end{array}$ & 11 & Ya & $\hat{\xi}$ \\
\hline 2 & $\begin{array}{l}\text { Memperbaiki } \\
\text { trafo }\end{array}$ & 14 & Tidak & - \\
\hline 3 & $\begin{array}{l}\text { Mengganti } \\
\text { dengan } \\
\text { persediaan } \\
\text { trafo yang ada }\end{array}$ & 16 & Tidak & - \\
\hline
\end{tabular}

Tabel 4.1 : Hasil Keputusan Manajemen Risiko

\section{Keterangan}

1. “ 5 adalah tanda bahwa solusi bernilai terkecil, maka sistem program akan menjadikan solusi tersebut sebagai suatu rekomendasi untuk penyelesaian sebuah permasalahan.

2. "Ya" adalah tanda bahwa Tim atau Manajer Manajemen Risiko sudah menyetujui atau menerima solusi yang rekomendasikan oleh sistem program.

Membeli trafo yang baru menjadi solusi yang disetujui dan dijadikan sebagai keputusan oleh Tim atau Manajer Manajemen Risiko.
3. “Tidak" adalah tanda bahwa solusi tidak disetujui oleh Tim atau Manajer Manajemen Risiko.

Memperbaiki trafo dan mengganti dengan persediaan trafo tidak termsuk solusi yang disetujui.

\section{Kesimpulan}

Kesimpulan dari pembuatan software Program

Bantu Sistem Analisis Manajemen Risiko adalah

1. Software ini merupakan bank data yang berisi data tersedianya perangkat, potensi dan suber daya yang ada.sehingga seluruh aspek yang menyangkut infrastruktur dalam perusahaan.

2. Memberikan informasi berupa rekomendasi untuk mengambil sebuah keputusan. Rekomendasi ini sifatnya tidak mutlak untuk pembenaran sebuah hasil keputusan

3. Rekomendasi yang dimunculkan adalah berupa uraian solusi berdasarkan level risiko.

4. Sistem ini bersifat fleksibel sehingga kebutuhan data, solusi dan risiko bisa diedit dan ditambah maupun dikurangi

5. Mencakup inventarisasi barang yang dimiliki perusahaan

6. Dapat dijadikan sebagai standart operasional prosedur (SOP) untuk sebuah pekerjaan.

7. Manajemen data bersifat terstruktur dan fleksibel, tidak memerlukan data dalam buku.

8. Sistem ini bersifat cerdas sehingga mampu membedakan data yang akan dimasukkan dengan data yang sudah ada.

\section{Daftar Pustaka}

[1] Cooper, Tutorial Notes; The Australian and New Zealand Standart on Risk Management, AS/NZS 4360:2004. Broadleaf Capital International Pty Ltd.

[2] Darmawi, Herman. (2005). Manajemen risiko (cet. 9). Bumi Aksara, Jakarta.

[3] Ronitua Harahap, Pardamean. Asian Business Consultants.

[4] Trieschmann, James S., and Gustavson, Sandra G. (1995). Risk management and insurance (9th ed.). South-Western College Publishing.

[5] Indra, Agus. (2008). Manajemen Resiko Berbasis Kowledge Management PT. PLN Distribusi Jawa Timur. Elista Surabaya, Designer Implementator.

[6] Leonita, Elisabeth (2007), Analisa Penanganan Risiko Melalui Pendekatan Sistem Manajemen Risiko Dalam Bisnis Real Estate di Surabaya. Pasca Sarjana Teknik Sipil Universitas Kristen Petra Surabaya. 